\title{
New monomers for (bi)pyridine-containing polymers
}

\author{
A. P. Krinochkin ${ }^{\text {ab }}$, M. I. Savchuk, \\ E.S. Starnovskaya ${ }^{a b}$, Y. K. Shtaitz ${ }^{a}$, D.S. Kopchuk ${ }^{\text {ab }}$, \\ I. L. Nikonov ${ }^{\text {ab }}$, I.S. Kovalev ${ }^{\text {a }}$, G. V. Zyryanov ${ }^{\text {ab* }}$, \\ V.L. Rusinov ${ }^{\mathrm{ab}}$, O.N. Chupakhin ${ }^{\mathrm{ab}}$ \\ ${ }^{a}$ Ural Federal University named after the first President of Russia B. N. Yeltsin, \\ 19 Mira st., Ekaterinburg, 620002, Russian Federation \\ ${ }^{b}$ I. Ya. Postovsky Institute of Organic Synthesis of RAS (Ural Branch), \\ 22/20 S. Kovalevskoy/Akademicheskaya st., \\ Ekaterinburg, 620990, Russian Federation \\ *email: g.v.zyrianov@urfu.ru
}

Abstract. Convenient methods for the synthesis of three monomers based on functionalized (bi)pyridines with using "1,2,4-triaizine" methodology have been developed.

Keywords: monomers; 1,2,4-triazines; (bi)pyridines; inverse demand Diels-Alder reaction

Received: 09.09.2020. Accepted: 20.12.2020. Published:30.12.2020.

(c) Krinochkin A. P., Savchuk M. I., Starnovskaya E. S., Shtaitz Y. K., Kopchuk D. S., Nikonov I. L., Kovalev I. S., Zyryanov G. V., Rusinov V. L., Chupakhin 0. N., 2020

\section{Introduction}

$\left(2,2^{\prime}\right.$-Bi)pyridine containing polymers are of interest from the point of view of creating OLED $[1,2]$ for redox catalytic reactions [3], as electrolyte membrane fuel cell application [4] or anode materials components [5]. In this regard, the development of convenient methods for the synthesis of compounds with the (poly) pyridine fragment and suitable for using as monomers, is an actual purpose. In this article we propose the convenient methods for the synthesis of three potential monomers of the (bi)pyridine series.

\section{Experimental part}

${ }^{1} \mathrm{H}$ NMR spectra were recorded on a Bruker Avance-400 spectrometer $(400 \mathrm{MHz})$, the internal standard was $\mathrm{SiMe}_{4}$. Mass-spectra (ionization type - electrospray) were recorded on a MicrOTOF-Q II instrument from Bruker Daltonics (Bremen, Germany). Elemental analysis was performed on a Perkin Elmer PE 2400 II CHN analyzer. The starting 4-bromophenylhydrazone 2 was obtained according to the described method [11].
General procedure for the synthesis of 1,2,4-triazines 3

Hydrazone 2 (605 mg, $2.5 \mathrm{mmol}$ ) was solved in ethanol $(30 \mathrm{ml})$ and solution of the corresponding carbaldehyde 1 $(2.5 \mathrm{mmol})$ in ethanol $(25 \mathrm{ml})$ was added. The resulting mixture was kept at room temperature for $12 \mathrm{~h}$. The precipitate was filtered off, washed with ethanol and dried. Then the obtained intermediate was suspended in acetic acid $(30 \mathrm{ml})$ and mixture was heated to reflux two times. Solvent was removed under reduced pressure. 
Ethanol $(30 \mathrm{ml})$ was added to the residue; the resulting crystals of $\mathbf{3}$ were filtered off, washed with ethanol and dried. The crude triazines were used directly in the next step without additional purification.

6-(4-Bromophenyl)-3-(5-bromopyridin-2-yl)-1,2,4-triazine (3a). Yield $630 \mathrm{mg}$ (1.60 mmol, 64\%). NMR ${ }^{1} \mathrm{H}$ (DMSO- $d_{6}, \delta$, ppm): 7.75-7.79 (m, 2H, $\mathrm{C}_{6} \mathrm{H}_{4} \mathrm{Br}$ ), 8.23 (dd, $1 \mathrm{H},{ }^{3} J 8.4 \mathrm{~Hz},{ }^{4} \mathrm{~J} 2.4 \mathrm{~Hz}, \mathrm{H}-4($ py) $), 8.25-8.29$ $\left(\mathrm{m}, 2 \mathrm{H}, \mathrm{C}_{6} \mathrm{H}_{4} \mathrm{Br}\right), 8.49$ (d, $1 \mathrm{H},{ }^{3} \mathrm{~J} 8.4 \mathrm{~Hz}$, H-5(py)), 8.89 (d, 1H, ${ }^{4}$ 2.4 Hz, H-6(py)), 9.52 (s, 1H, H-5). ESI-MS, m/z: 390.92 $(\mathrm{M}+\mathrm{H})^{+}$.

6-Bromo-2-(6-(4-bromophenyl)1,2,4-triazin-3-yl)quinoline (3b). Yield $800 \mathrm{mg}$ (1.80 mmol, 72\%). NMR ${ }^{1} \mathrm{H}$ (DMSO- $\left.d_{6}, \delta, \mathrm{ppm}\right): 7.77-7.83(\mathrm{~m}, 2 \mathrm{H}$, $\left.\mathrm{C}_{6} \mathrm{H}_{4} \mathrm{Br}\right), 7.92\left(\mathrm{dd}, 1 \mathrm{H},{ }^{3} J 8.0 \mathrm{~Hz},{ }^{4} J 2.0 \mathrm{~Hz}\right.$, $\mathrm{H}-7$ (qui)), 8.15-8.20 (m, 2H, H-5,8(qui)), 8.30-8.35 (m, 2H, $\mathrm{C}_{6} \mathrm{H}_{4} \mathrm{Br}$ ), 8.56 and 8.70 (both d, $1 \mathrm{H},{ }^{3} \mathrm{~J} 8.4 \mathrm{~Hz}, \mathrm{H}-3$ and $\mathrm{H}-4$ (qui)), 9.61 (s, 1H, H-5). ESI-MS, m/z: 440.94 $(\mathrm{M}+\mathrm{H})^{+}$.

3-(4-Bromophenyl)-6-(thiophen2-yl)-1,2,4-triazine (7). A mixture of $349 \mathrm{mg}(1.7 \mathrm{mmol})$ of 2-bromo1-(thiophen-2-yl)ethanone 5, $732 \mathrm{mg}$ (3.4 mmol) of hydrazide 6 and $25 \mathrm{~mL}$ of DMF was heated at $120^{\circ} \mathrm{C}$ under argon for $10 \mathrm{~h}$. The solvent was distilled off under reduced pressure, the residue was treated with ethanol, and the precipitate was filtered off. The crude triazine was used directly in the next step without addition purification. Yield $343 \mathrm{mg}$ (1.08 mmol, 63\%). NMR ${ }^{1} \mathrm{H}$ (DMSO- $\left.d_{6}, \delta, \mathrm{ppm}\right): 7.27$ (dd, $1 \mathrm{H},{ }^{3} J 5.2$ $\mathrm{Hz}, 3.8 \mathrm{~Hz}, \mathrm{H}-4$ (thio)), 7.70-7.76 (m, 2H, $\mathrm{C}_{6} \mathrm{H}_{4} \mathrm{Br}$ ), 7.27 (dd, $1 \mathrm{H},{ }^{3} \mathrm{~J} 5.2 \mathrm{~Hz},{ }^{4} \mathrm{~J} 0.8 \mathrm{~Hz}$, $\mathrm{H}-5$ (thio)), 8.10 (dd, $1 \mathrm{H},{ }^{3} \mathrm{~J} 3.8 \mathrm{~Hz},{ }^{4} \mathrm{~J} 0.8$ $\mathrm{Hz}, \mathrm{H}-3$ (thio)), 8.37-8.42 (m, 2H, $\mathrm{C}_{6} \mathrm{H}_{4} \mathrm{Br}$ ), 9.43 (s, 1H, H-5).
A general procedure for the synthesis of (bi)pyridines 4 and 8

The mixture of corresponding 1,2,4-triazine 3 or $7(0.8 \mathrm{mmol})$ and 1-morpholinocyclo-pentene $(0.64 \mathrm{ml}, 4.0 \mathrm{mmol})$ was stirred at $200{ }^{\circ} \mathrm{C}$ for $2 \mathrm{~h}$ under argon atmosphere. Then, the additional portion of 1-morpholinocyclopentene $(0.32 \mathrm{ml}$, $2.0 \mathrm{mmol}$ ) was added and the resulting mixture was stirred for additional $1 \mathrm{~h}$ at the same conditions. The reaction mass was cooled to room temperature. The products were purified by flash chromatography (DCM as eluent) and then by recrystallization (ethanol).

4-(4-Bromophenyl)-1-(5-bromopyridin-2-yl)-6,7-dihydro-5H-cyclopenta $[c]$ pyridine (4a). Yield $270 \mathrm{mg}(0.63 \mathrm{mmol}$, 78\%). NMR ${ }^{1} \mathrm{H}$ (DMSO- $\left.d_{6}, \delta, \mathrm{ppm}\right): 2.08$ (m, 2H, $\left.\mathrm{CH}_{2}-6\right), 3.04$ (t, 2H, ${ }^{3} J 7.6 \mathrm{~Hz}$, $\left.\mathrm{CH}_{2}-7\right), 3.46\left(\mathrm{t}, 2 \mathrm{H},{ }^{3} \mathrm{~J} 7.6 \mathrm{~Hz}, \mathrm{CH}_{2}-5\right)$, 7.48-7.54 (m, 2H, $\left.\mathrm{C}_{6} \mathrm{H}_{4} \mathrm{Br}\right), 7.64-7.70$ (m, $\left.2 \mathrm{H}, \mathrm{C}_{6} \mathrm{H}_{4} \mathrm{Br}\right), 8.11\left(\mathrm{dd}, 1 \mathrm{H},{ }^{3} \mathrm{~J} 8.4 \mathrm{~Hz},{ }^{4} \mathrm{~J} 1.6\right.$ $\left.\mathrm{Hz}, \mathrm{H}-4^{\prime}\right), 8.30$ (d, $\left.1 \mathrm{H},{ }^{3} \mathrm{~J} 8.4 \mathrm{~Hz}, \mathrm{H}-5^{\prime}\right), 8.47$ (s, 1H, H-3), 8.75 (d, 1H, $\left.{ }^{4} J 1.6 \mathrm{~Hz}, \mathrm{H}-6^{\prime}\right)$. ESI-MS, m/z: $428.96(\mathrm{M}+\mathrm{H})^{+}$. Found, \%: C 53.19, H 3.39, N 6.40. $\mathrm{C}_{19} \mathrm{H}_{14} \mathrm{Br}_{2} \mathrm{~N}_{2}$. Calculated, \%: C 53.05, H 3.28, N 6.51.

6-Bromo-2-(4-(4-bromophenyl)6,7-dihydro-5 $H$-cyclopenta[c]pyridin1-yl)quinoline (4b). Yield $290 \mathrm{mg}(0.60$ mmol, 75\%). NMR ${ }^{1} \mathrm{H}$ (DMSO- $\left.d_{6}, \delta, \mathrm{ppm}\right)$ : $2.14\left(\mathrm{~m}, 2 \mathrm{H}, \mathrm{CH}_{2}-6\right), 3.08\left(\mathrm{t}, 2 \mathrm{H},{ }^{3} \mathrm{~J} 7.6\right.$ $\mathrm{Hz}, \mathrm{CH}_{2}-7$ ), 3.69 (t, 2H, ${ }^{3} \mathrm{~J} 7.6 \mathrm{~Hz}, \mathrm{CH}_{2}$ 5), 7.51-7.57 (m, 2H, $\left.\mathrm{C}_{6} \mathrm{H}_{4} \mathrm{Br}\right), 7.66-7.71$ $\left(\mathrm{m}, 2 \mathrm{H}, \mathrm{C}_{6} \mathrm{H}_{4} \mathrm{Br}\right), 7.86\left(\mathrm{dd}, 1 \mathrm{H},{ }^{3} J 8.8 \mathrm{~Hz}\right.$, ${ }^{4} J 1.6 \mathrm{~Hz}, \mathrm{H}-7$ (qui)), $8.02\left(\mathrm{~d}, 1 \mathrm{H},{ }^{3} J 8.8 \mathrm{~Hz}\right.$, $\mathrm{H}-8$ (qui)), (d, 1H, ${ }^{4} J 1.6 \mathrm{~Hz}, \mathrm{H}-5$ (qui)), 8.40 and 8.56 (both $\mathrm{d}, 1 \mathrm{H},{ }^{3} \mathrm{~J} 8.8 \mathrm{~Hz}, \mathrm{H}-3$ and $\mathrm{H}-4$ (qui)), 8.54 (s, 1H, H-3). ESI-MS, $\mathrm{m} / \mathrm{z}: 478.98(\mathrm{M}+\mathrm{H})^{+}$. Found, \%: C 57.41, H 3.22, N 8.67. $\mathrm{C}_{23} \mathrm{H}_{16} \mathrm{Br}_{2} \mathrm{~N}_{2}$. Calculated, \%: C 57.53, H 3.36, N 8.53. 
1-(4-Bromophenyl)-4-(thiophen2-yl)-6,7-dihydro-5H-cyclopenta [c] pyridine (8). Yield $228 \mathrm{mg}(0.64 \mathrm{mmol}$, 80\%). NMR ${ }^{1} \mathrm{H}$ (DMSO- $\left.d_{6}, \delta, \mathrm{ppm}\right): 2.14$ (m, $\left.2 \mathrm{H}, \mathrm{CH}_{2}-6\right), 3.15\left(\mathrm{t}, 2 \mathrm{H},{ }^{3} \mathrm{~J} 7.6 \mathrm{~Hz}, \mathrm{CH}_{2}\right.$ 7), 3.20 (t, 2H, $\left.{ }^{3} 7.6 \mathrm{~Hz}, \mathrm{CH}_{2}-5\right), 7.16$ (dd, $1 \mathrm{H},{ }^{3} \mathrm{~J} 5.2 \mathrm{~Hz}, 3.8 \mathrm{~Hz}, \mathrm{H}-4$ (thio)), 7.33 (dd, $1 \mathrm{H},{ }^{3} J 3.8 \mathrm{~Hz},{ }^{4} J 0.8 \mathrm{~Hz}, \mathrm{H}-3$ (thio)), 7.41 (dd, $1 \mathrm{H},{ }^{3} \mathrm{~J} 5.2 \mathrm{~Hz},{ }^{4} J 0.8 \mathrm{~Hz}, \mathrm{H}-5$ (thio)), 7.57-7.62 (m, 2H, C $\left.\mathrm{H}_{4} \mathrm{Br}\right), 7.65-7.70$ (m, $2 \mathrm{H}, \mathrm{C}_{6} \mathrm{H}_{4} \mathrm{Br}$ ), 8.73 (s, 1H, H-3). ESI-MS, $\mathrm{m} / \mathrm{z}$ : $356.01(\mathrm{M}+\mathrm{H})^{+}$. Found, \%: C 60.53, $\mathrm{H} 3.81, \mathrm{~N}$ 4.07. $\mathrm{C}_{18} \mathrm{H}_{14}$ BrNS. Calculated, \%: C 60.68, H 3.96, N 3.93.

1-(4-Bromophenyl)-4-(5-bromothiophen-2-yl)-6,7-dihydro-5H-cyclopenta[c] pyridine (9). Pyridine 8 (307 mg, 0.86 mmol) was dissolved in DMF (30 mL). $N$ Bromosuccinimide (184 mg, $1.0 \mathrm{mmol}$ ) was added and the resulting mixture was stirred for $8 \mathrm{~h}$ at $50{ }^{\circ} \mathrm{C}$. Then water $(100 \mathrm{~mL})$ was added to the mixture and precipitate formed was filtered off. The analytical sample was obtained by recrystallization (ethanol). Yield $329 \mathrm{mg}(0.76 \mathrm{mmol}$, 88\%). NMR ${ }^{1} \mathrm{H}\left(\mathrm{CDCl}_{3}, \delta, \mathrm{ppm}\right): 2.19$ (m, $\left.2 \mathrm{H}, \mathrm{CH}_{2}-6\right), 3.17$ (t, $2 \mathrm{H},{ }^{3} \mathrm{~J} 7.6 \mathrm{~Hz}, \mathrm{CH}_{2}-$ 7), $3.20\left(\mathrm{t}, 2 \mathrm{H},{ }^{3} \mathrm{~J} 7.6 \mathrm{~Hz}, \mathrm{CH}_{2}-5\right), 7.10$ and 7.13 (d, $1 \mathrm{H},{ }^{3} \mathrm{~J} 3.8 \mathrm{~Hz}, \mathrm{H}-3$ and $\mathrm{H}-4$ (thio)), 7.61-7.65 (m, 2H, $\mathrm{C}_{6} \mathrm{H}_{4} \mathrm{Br}$ ), 7.67-7.71 (m, $2 \mathrm{H}, \mathrm{C}_{6} \mathrm{H}_{4} \mathrm{Br}$ ), 8.69 (s, 1H, H-3). ESI-MS, $\mathrm{m} / \mathrm{z}: 433.92(\mathrm{M}+\mathrm{H})^{+}$. Found, \%: C 49.53, $\mathrm{H} 3.14, \mathrm{~N} 3.39 . \mathrm{C}_{18} \mathrm{H}_{13} \mathrm{Br}_{2} \mathrm{NS}$. Calculated, \%: C 49.68, H 3.01, N 3.22.

\section{Results and discussion}

The "1,2,4-triazine" methodology has been used for the preparation of the target compounds [7-9]. In particular, we used the modified synthetic route previously used for preparation of the luminophores of 2,2'-bipyridine [10] and 2-(2-pyridyl) quinoluine series [11]. Namely, heterocyclization [6] of the corresponding commercially available aldehydes $\mathbf{1 a}, \mathbf{b}$ and hydrazone of 4'-bromoisonitrosoacetophenone 2 [11] allowed to obtain the 1,2,4-triazine precursors 3, which are also of interest as monomers (Scheme 1). The further solvent-free inverse demand Diels-Alder reaction with 1-morpholinocyclopentene [12] allowed to synthesize compounds 4 of 2,2'-bipyridine and 2-(2-pyridyl)quinoluine series.

We have also suggested an approach for obtaining the monomer of monopyridine series. In this case we also used the "1,2,4-triazine" methodology. Namely,

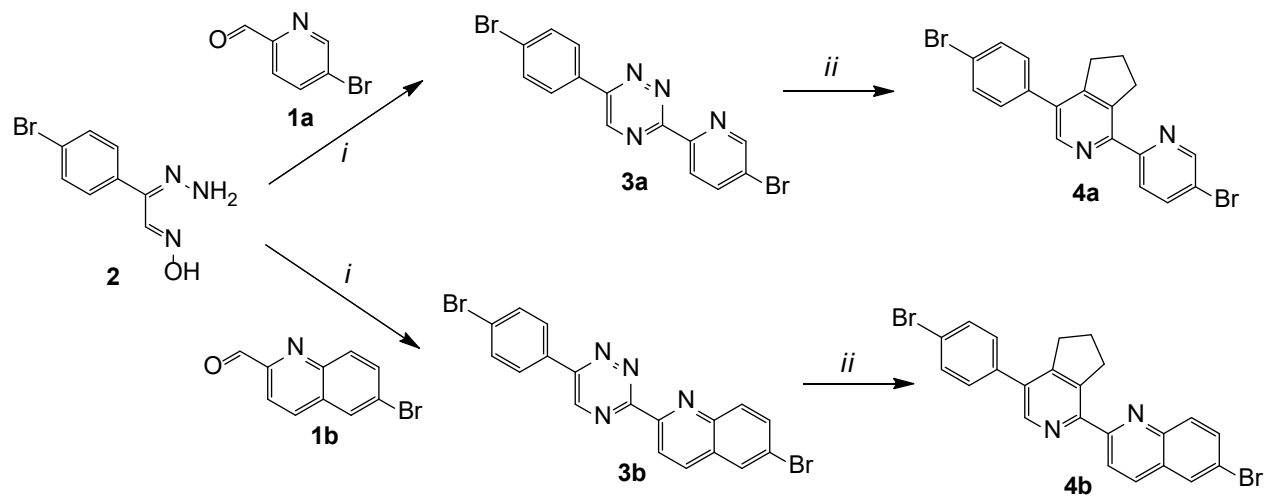

Scheme 1. Reagents and conditions: i) 12 h, r.t. / EtOH, then $\mathrm{AcOH}, 118^{\circ} \mathrm{C}, 5 \mathrm{~min}$; ii) 1-morpholinocyclopentene, $200{ }^{\circ} \mathrm{C}$, neat, $3 \mathrm{~h}$. 




Scheme 2. Reagents and conditions: i) DMF, $120^{\circ} \mathrm{C}, 10 \mathrm{~h}$; ii) 1-morpholinocyclopentene, $200{ }^{\circ} \mathrm{C}$, neat, $3 \mathrm{~h}$; iii) NBS, $50{ }^{\circ} \mathrm{C}, 8 \mathrm{~h}$.

the condensation of 2-bromoacetylthiophene 5 with two equivalents of hydrazide of 4-bromobenzoic acid 6 allowed to obtain the triazine precursor 7 (Scheme 2). This heterocyclization has been known for a long time [13]. In this case reaction was realized during heating in DMF with no sodium acetate $[14,15]$. The further solvent-free inverse demand Diels-Alder reaction [12] with 1-morpholinocyclopentene allowed to obtain the condendes pyridine 8. For preparation of monomer 9 we used the bromination of thiophene ring of compound 8 at position C5 by $\mathrm{N}$ bromosuccinimide in DMF. This reaction is a well-known effective method $[16,17]$. For the full conversion of compound $\mathbf{8}$ to 9 it is necessary the heating reaction mass at $50^{\circ} \mathrm{C}$.

The structure of compounds 4 and 9 was confirmed by data of NMR ${ }^{1} \mathrm{H}$, mass-spectrometry and elemental analysis. The characteristics of compounds 4 correlate with ones for the previously published similar compounds [10, 11]. For compound 9 there are the signals of protons of thiophene ring as two doublets, protons of cyclopentene fragment, protons of 4-bromophenyl moiety, as well as proton of 6,7-dihydro- $5 \mathrm{H}$ cyclopenta $[c]$ pyridine as singlet.

\section{Conclusions}

In conclusion, we have reported herein effective synthetic protocols for the preparation of functionalized (bi)pyridines

as potential monomers for the further synthesis of (bi)pyridines-based polymers for different applications.

\section{Acknowledgements}

This work was supported by the Russian Foundation for Basic Research (Grant \#19-53-55002) and Grants Council of the President of the Russian Federation (no. NSh-2700.2020.3).

\section{References}

1. Li ZR, editor. Organic Light-Emitting Materials and Devices. Boca Raton: CRC Press, 2015. $813 \mathrm{p}$.

2. Wang C, Kilitziraki M, MacBride JAH, Bryce MR., Horsburgh LE, Sheridan AK, Monkman AP, Samuel IDW. Tuning the optoelectronic properties of pyridinecontaining polymers for light-emitting devices. Adv Mater. 2000;12:217-22. doi:10.1002/(SICI)1521-4095(200002)12:3<217::AID-ADMA217>3.0.CO;2-Y 
3. Sato Y, Kagotani M, Yamamoto T, Souma Y. Novel Effective Poly(2,2'-Bipyridine$5,5^{\prime}$-Diyl)-CuCl${ }_{2}$ Catalyst for Synthesis of Dimethyl Carbonate (DMC) by Oxidative Carbonylation of Methanol. Appl Catal A-Gen. 1999;185:219-26.

doi:10.1016/S0926-860X(99)00175-1

4. Xiao L, Zhang H, Jana T, Scanlon E, Chen R, Choe E-W, Ramanathan LS, Yu S, Denicewicz BC. Synthesis and characterization of pyridine-based polybenzimidazoles for high temperature polymer electrolyte membrane fuel cell applicationsx. Fuel cells. 2005;5:287-95. doi:10.1002/fuce.200400067

5. Yang L, Mihali V-A, Brandell D, Strømme M, Sjödin M. Conjugated Pyridine-Based Polymers Characterized as Conductivity Carrying Components in Anode Materials. J Phys Chem C. 2014;118:25956-63. doi:10.1021/jp509606c

6. Kozhevnikov VN, Kozhevnikov DN, Shabunina OV, Rusinov VL, Chupakhin ON. An efficient route to 5-(hetero)aryl-2,4' - and 2,2' -bipyridines through readily available 3-pyridyl-1,2,4-triazines. Tetrahedron Lett. 2005;46:1791-3. doi:10.1016/j.tetlet.2005.01.135

7. Pabst GR, Sauer J. A new and simple 'LEGO' system for the synthesis of 2,6-oligopyridines. Tetrahedron Lett. 1998;39:6687-90. doi:10.1016/S0040-4039(98)01437-3

8. Rykowski A, Branowska D, Kielak J. A novel one-pot synthesis of annulated 2,2'-bipyridine ligands by inverse electron demand Diels - Alder reaction of 5,5' -bi1,2,4-triazines. Tetrahedron Lett. 2000;41:3657-9. doi:10.1016/S0040-4039(00)00436-6

9. Kozhevnikov VN, Shabunina OV, Kopchuk DS, Ustinova MM, König B, Kozhevnikov DN. Facile synthesis of 6-aryl-3-pyridyl-1,2,4-triazines as a key step toward highly fluorescent 5-substituted bipyridines and their $\mathrm{Zn}$ (II) and $\mathrm{Ru}(\mathrm{II})$ complexes. Tetrahedron. 2008;64:8963-73.

doi:10.1016/j.tet.2008.06.040

10. Starnovskaya ES, Kopchuk DS, Khasanov AF, Tanya OS, Santra S, Giri K, Rahman M, Kovalev IS, Zyryanov GV, Majeed A, Charushin VN. Synthesis and photophysics of new unsymmetrically substituted 5,5'-diaryl-2,2'-bypiridine-based "push-pull" fluorophores. Dyes Pigm. 2019;162:324-30.

doi:10.1016/j.dyepig.2018.10.040

11. Kopchuk DS, Chepchugov NV, Starnovskaya ES, Khasanov AF, Krinochkin AP, Santra S, Zyryanov GV, Das P, Majee A, Rusinov VL, Charushin VN. Synthesis and optical properties of new 2-(5-arylpyridine-2-yl)-6-(het)arylquinoline-based "pushpull" fluorophores. Dyes Pigm. 2019;167:151-6.

doi 10.1016/j.dyepig.2019.04.029

12. Kozhevnikov VN, Ustinova MM, Slepukhin PA, Santoro A, Bruce DW, Kozhevnikov DN. From 1,2,4-triazines towards substituted pyridines and their cyclometallated Pt complexes. Tetrahedron Lett. 2008;49:4096-8.

doi:10.1016/j.tetlet.2008.04.138 
13. Saraswathi TV, Srinivasan VR. A novel synthesis of 1,2,4-triazines. Tetrahedron Lett. 1971;12:2315-6.

doi:10.1016/S0040-4039(01)96849-2

14. Saraswathi TV, Srinivasan VR. Syntheses and spectral characteristics of 6-mono-, 3,6-di and 3,5,6-trisubstituted-1,2,4-triazines. Tetrahedron. 1977;33:1043-51. doi:10.1016/0040-4020(77)80223-8

15. Shtaitz YaK, Savchuk MI, Kopchuk DS, Taniya OS, Santra S, Zyryanov GV, Suvorova AI, Rusinov VL, Chupakhin ON. Efficient Synthesis of Methyl 6-(6-Aryl-1,2,4-triazin-3-yl)pyridine-2-carboxylates. Russ J Org Chem. 2020;56:548-51. doi:10.1134/S1070428020030306

16. Khan MS, Al-Mandhary MRA, Al-Suti MK. Feeder N, Nahar S, Koehler A, Friend RH, Wilson PJ, Raithby PR. Synthesis, characterisation and electronic properties of a series of platinum(II) poly-ynes containing novel thienyl-pyridine linker groups. Dalton Trans. 2002;12:2441-8. doi:10.1039/B201073A

17. Hu B, Fu S-J, Xu F, Tao T, Zhu H-Y, Cao K-S, Huang W, You X-Z. Linear heterocyclic aromatic fluorescence compounds having various donor-acceptor spacers prepared by the combination of carbon-carbon bond and carbon-nitrogen bond cross-coupling reactions. J Org Chem. 2011;76:4444-56.

doi:10.1021/jo200065d 